\title{
THE RISE OF ISLAMIC RELIGIOUS-POLITICAL MOVEMENTS IN INDONESIA The Background, Present Situation and Future ${ }^{1}$
}

\author{
Hamid Fahmy Zarkasyi \\ The Institute for Islamic Studies of Darussalam, Gontor \\ Ponorogo, Indonesia
}

\begin{abstract}
This paper traces the roots of the emergence of Islamic religious and political movements in Indonesia especially during and after their depoliticization during the New Order regime. There were two important impacts of the depoliticization, first, the emergence of various study groups and student organizations in university campuses. Second, the emergence of Islamic political parties after the fall of Suharto. In addition, political freedom after long oppression also helped create religious groups both radical on the one hand and liberal on the other. These radical and liberal groups were not only intellectual movements but also social and political in nature. Although the present confrontation between liberal and moderate Muslims could lead to serious conflict in the future, and would put the democratic atmosphere at risk, the role of the majority of the moderates remains decisive in determining the course of Islam and politics in Indonesia.
\end{abstract}

Keywords: Islamic religious-political movement, liberal Islam, non-liberal Indonesian Muslims.

\section{Introduction}

The rise of Islamic political parties and Islamic religious movements after the fall of Suharto was not abrupt in manner. The process was gradual, involving numbers of national and global factors.

\footnotetext{
1 The earlier version of this paper was presented at the conference "Islam and Asia: Revisiting the Socio-Political Dimension of Islam," jointly organized by Japan Institute of International Affairs (JIIA) and Institute of Islamic Understanding Malaysia (IKIM), 15-16 October, Tokyo.
} 
Under the Sukarno and Suharto regimes, Muslim students' and political movements suffered political oppression, but this merely had the effect of encouraging Muslims to mobilize themselves through underground organizations and movements. The resignation of President Suharto and the succession of his Vice President, B.J. Habibie in 1998 marked the end of four decades of authoritarian rule and the beginning of democratization in Indonesian politics. The era of authoritarian rule, with considerable restriction and repression in socio-political life, was subsequently replaced by the so-called Reformation Era with its extravagant euphoria of freedom. Repression against Muslim and other groups decreased somewhat under the Habibie regime and dramatically under the regime of Abdurrahman Wahid. Habibie started by lifting the existing ban on the number of political parties and announced that a general election would be held within a year. He also abolished the regulation of the media. Wahid, who was later known as a pluralist figure, began by lifting the ban on ex-communist party members participating in social and political activities. ${ }^{2}$ The situation became considerably more conducive for the rise of diverse movements of various ideologies, the two most interesting being the rise of Islamic political parties, and the emergence of Muslim groups regarded as taking extreme positions either radical extremist group or extreme liberal groups. This paper will analyze the rise of those movements from their background, the present situation, and finally, the future.

\section{Brief Historical Background}

Studies on the current rise of political Islam in Indonesia presuppose the study of the longstanding historical process of the Muslim struggle in building a nation state, prior to and after independence. Indonesia is the world's largest Muslim population and is the world's fourth most populous nation overall. It embraces within its territorial boundaries the largest concentration of Muslims in the world. From its total population of more than 210 million, $87 \%$ are listed as Muslim. Moreover, as the religion of the majority, Islam and its institutions historically played a pivotal role in mobilizing and organizing the masses against the colonialist power. Prior to

\footnotetext{
2 After he steps down from his power Wahid appreciate the launching the publication of the translated Karl Marx book Das Capital. The students who were present at the event commented that Islam should learn from communism.
} 
independence Islamic organizations in Indonesia were also among those who spearheaded the Indonesian nationalist movements. Countless Muslim politicians, educators, social and religious leaders and others took part in the struggle for Indonesian independence. The establishment of Syarikat Islam in early 1920s, comprising Muslim traders from Java and Sumatra, provides evidence of such social mobilization. In addition, traditional educational institutions, like pesantren with their religious scholars (ulama)? also displayed a remarkable ability to mobilize forces against the Dutch colonialists. The formation and collaboration of PETA (National Defenders) and Hizbullah (The Army of God) during the Japanese occupation bear further witness to this. ${ }^{3}$

After independence Muslims were the key actors in the formation of the new state and even in the building of the nation as a whole. However, these Islamic social movements, like Islam itself, were not monolithic. Rather, the movements were comprised of a diverse array of Muslim actors with different goals and myriad means by which they sought to achieve their objectives. Some social movements might seek an Islamic state by winning elections, others attempted to implement Islamic laws among the Muslim community, others sought to improve the system of Islamic education through establishing schools, universities, or training centers, while other groups aimed to create their own economic systems and the like. In short, Islam became the major impetus and the unifying factor of the Indonesian nation that formed the Indonesian state. However, after long debate among the founding fathers of Indonesia the idea of an Islamic state supported by Muslim leaders was rejected in favor of a unitary state.

In the early twentieth century two important organizations were established. First, Muhammadiyah, which was formed in 1912 to assert reformist or "modern" Islamic ideals. To date, it is the second largest Islamic organization in the country and has 9,527 educational institutions of various types, and 3,775 health and welfare-related centers. Second as a counterweight to Muhammadiyah, in 1926 an organization reflecting the traditionalist outlook was established under the name Nabdatul Ulama (literally, "revival of the religious teachers,"

\footnotetext{
${ }^{3}$ For the history of PETA and Hizbullah formation, see Harry J. Benda, the Crescent on the Rising Sun, Indonesian Islam under the Japanese Occupation, 1942-1945 (Netherlands: The Hague - W. Van Hoeve, 1958).
} 
but commonly referred to as the Muslim Scholars' League). This organization is now the largest Islamic organization in Indonesia, claiming to have hundreds of traditional schools (pesantren) and 30 million supporters. It runs schools and community associations throughout the country. Interestingly, the founders of both NU and Muhammadiyah graduated from Saudi Arabia in 19th century, during which time Mecca and Medina were the centers of traditional learning. They were known to hold and practice a fundamental teaching of Islam, but not necessarily "fundamentalist" in the Western sense of the term. During the struggle for Indonesian independence, which was finally declared in 1945, the prominent figures of these two organizations became committee members for the preparation of Indonesian Independence (PPKI).

After the proclamation of Indonesian independence in 1945, a large number of competing parties emerged. Among these parties Masyumi (Indonesian Muslim Consultative Council) was in a strong position. Masyumi was a federation of Islamic parties and organizations, including Muhammadiyah, Syarekat Islam and Nabdlatul Ulama. Its leader was Mohammad Natsir who during the early period of parliamentary democracy (1950 - 1957) became Prime Minister (from September 1950 to March 1951). Within the first decade, strains among the party members begun to emerge. Syarekat Islam party (in 1948) and Nahdatul Ulama (in 1950) withdrew from Masyumi. Nonetheless, in 1955 election Masyumi still won 22 percent of parliamentary vote, equal to forty-four seats. However, due to the hostility of party members toward Sukarno, the party was then banned in 1960.4

During the New Order regime, under the leadership of Suharto, the Muslim parties were oppressed. Pancasila was established as the state ideology and Suharto expressed his intention to do away with parties based on religion. He then decided to reduce the number of

\footnotetext{
${ }^{4}$ Since then Natsir change his activity into social movement. He established the Dewan Dakwah Islamiyah Indonesia (Indonesian Council for Islamic Propagation). It is an organization for the propagation of Islam, set up in 1968. Under the leadership of Natsir, who was also appointed as vice-president of the World Muslim Congress, the Council received financial support from the Saudi Arabia government. However, after his death the council receives no more financial support from the Saudis. For the explication of political development in these years see H. Faith, The Decline of Constitutional Democracy in Indonesia (Ithaca, N.Y.: Cornel University Press, 1962), esp. chapter $9 \& 10$.
} 
political parties. In the 1971 general election there were nine parties, four of them Muslim parties (PMI, NU, PSII, Tarbiyah). In 1973 the government merged these four parties into a single body identified by a name that had nothing to do with Islamic aspiration, the United Development Party (PPP). At the same time it merged five minority parties including the Catholic party, the Protestant party and the remnant of the former Indonesian Nationalist Party to form the Indonesian Democratic Party (PDI). Finally came the party that supported the government; Golkar. Thus, the number of parties at a single stroke was reduced to three parties, signaling the end of parties based on religious ideology.

Aside from the political situation in 1970s, there occurred, particularly among the Indonesian Muslims and generally among the youth in the Muslim world, certain mass religious phenomena,. In Indonesia these were called 'santri-ization', ${ }^{5}$ which means the increase of religious consciousness in Muslim society. This increasing public practice of their Islamic faith, like the consciousness to attend Friday prayers at the mosque, for women to wear the jilbab/tudung (Muslim head dress) and for Muslims to eat separately from non-Muslim colleagues has also characterized Malaysian and Singaporean Muslims. Although this change might be on the level of religious practice and not necessarily on religious thought or the substance of religious belief, it marked the rise of a greater awareness of Islam's global identity. Therefore, it should not be surprising that these phenomena occurred simultaneously with the growing support for the Palestinian cause. Thus, the increase of religious practices grew simultaneously with a global political awareness.

However, these phenomena suggest only religious identification, and cannot be generalized as the emergence of transnational terrorist networks nor the desire to establish exclusionist Islamic states in Southeast Asia. Usually observers correlate the phenomena with the 1979 Iranian Revolution or Wabhas school of thought. Indeed, the evidence that $W$ abhatrons ideas have been promoted in Pakistan, Afghanistan and Central Asia in the last thirty years through a variety

\footnotetext{
5 The santri refers to students of religious education institution named pesantren, seen as devout Muslims compared to the abangan nominal Muslims. In reality, this Clifford Geertz's old divisions are not so stark for there is a continuum that reflects the diverse practice of Islam in Muslim society. The discussion of the term in this article, however, refers to Koentjaraningrat, Javanese Culture (Singapore: Oxford University Press, 1985).
} 
of semi-official and official actors is undeniable. One would assume that the Taliban movement was "the final and the most formidable product of this long term strategy of Wahhabism."' However, so far Muslims in these areas remained Hanafi adherents and, in Southeast Asia, are Shafii strong holders. In Southeast Asia the Wahhabi influence can also be seen in the emergence of the group called Salafi, but it has nothing to do with the rise of religious movements, let alone the current political movement, since the school forbids its members to join any political activity. The spread of the Shi ${ }^{6} a b$ school of thought from Iran to South and Southeast Asia is also a irrefutable fact, but Muslims in these areas are still predominantly Sunni and not Shi $i$ like the Iranians. So the phenomena can hardly be traced from a single cause, or be inferred as the rise of extremism and radicalism. John $\mathrm{L}$ Esposito regards it as Islamic revivalism and a global reassertion of Islam that had already been under way and that extends from Libya to Malaysia. ${ }^{7}$

\section{Muslims under Oppression}

The above phenomena can be traced back to the Suharto regime, which can be appraised in two periods: first, from the late 1960s until the late 1980s and second from 1980 until the 1990s. In the first period the Suharto regime practiced highly indiscriminate repressive policies against Islamic organizations and sought to diffuse the Islamic threat by imposing ideological conformity on the majority of Islamic groups permitted to act politically. In the second period, Suharto permitted somewhat greater political openness (inclusion), and engaged in cosmetic competitive institution building. At the same time he also continued to apply repressive policies against Islam and any groups that posed a threat.

In the first period, that is to say the first two decades of the New Order regime, Suharto imposed strict controls on Islamic political organizations, as part of a systematic effort to depoliticize society and weaken the party system. After crushing the communists in 1965, Islamic extremists became the military's enemy number one. Since the

\footnotetext{
${ }^{6}$ Shireen T. Hunter, "Religion, Politics and Security in Central Asia," SAIS Review, 21, No. 2 (Summer-Fall 2001), pp. 72-81.

7 John L. Esposito, "Political Islam: Beyond the Green Menace," The Journal Current History, January (1994).
} 
military had had to suppress a series of Muslim revolts from 19481962, military officials had been thoroughly indoctrinated in the threat of Islamic extremism. ${ }^{8}$ Outside of its official corporatist institutions, the Suharto regime was intensely suspicious of Islamic groups and as such, religious extremists and their views were suppressed. Suharto's policy towards Islamic groups mirrored that of the Dutch colonial administration: it encouraged faith in Islam but ruthlessly repressed any political manifestations. ${ }^{9}$

In order to achieve these goals Suharto channeled Islamic group interests into nonparty national government-controlled associations like the Indonesian Council of Ulamas (MUI), the Indonesian Mosque Council (DMI) and the Indonesian Dakwah Council (MDI). The aim was to keep political participation and interest demands low by channeling group interest into state-supervised structures and locking them out of power-sharing agreements. ${ }^{10}$ It was also to demobilize, depoliticize and force Muslim groups go underground.

Towards the existing political parties Suharto applied the same strategy. He realized that there were numerous cleavages within the Islamic movement, with some parties, most notably Masyumi and its successor, Parmusi, favoring an Islamic state, while other parties wanted Indonesia to remain a Muslim country but not one governed under shariah law. In the wider political sphere, Suharto was also aware that Sukarno's supporters and other nationalist parties were still dangerous to his power and should be marginalized. Therefore in 1974 he allowed only three parties to compete in the following 1977 elections: four Islamic parties were forced to merge in to the Unity Development Party (PPP), non-Islamic parties, like PNI, were fused together as the Indonesian Democratic Party (PDI), and most significantly a government party was formed by the armed forces, the Joint Secretariat of Functional Groups (Golkar). Golkar was given primacy in rallying popular support for Suharto. Overall party influence was also minimized by restricting the parties' role in the newly established

\footnotetext{
${ }^{8}$ Michael Vatikiotis, Indonesian Politics under Subarto (London: Routledge, 1994), p. 127.

9 Robert W. Hefner, Civil Islam (Princeton: Princeton University Press, 2000), p. 121; Vatikiotis, Indonesian, p. 120; R. William Liddle, Leadership and Culture in Indonesian Politics (Sydney: Allen and Unwin, 1996), p. 621.

${ }^{10}$ Donald Porter, Managing Politics and Islam in Indonesia (London: Routledge, 2002), p. 4; Liddle, Leadership, p. 615.
} 
legislative bodies, the DPR, and the MPR. About 20\% of members were directly appointed by the government including representatives of the armed forces.

Merging Islamic parties into one Partai Persatuan Pembagunan (PPP), the Suharto regime forced it to abandon its Islamic symbol on the electoral ballot, and replaced the names of the parties with a single non-religious party name. ${ }^{11}$ The next step was to impose ideological conformity on Islamic political parties, organizations and statechartered religious institutions; all had to make Pancasila their operating and organizing principle. ${ }^{12}$ This strategy greatly contributed to the depoliticization of certain Islamic groups, a phenomenon that Donald Porter describes as effective in damaging religious organizations. ${ }^{13}$ This action was supposed to bring religious groups under state management and eliminate any unmediated Islamist tendencies. ${ }^{14}$ However, those groups which refused to give up their Islamic ideology and replace it by Pancasila went underground and operated covertly through informal networks, cell networks and through local mosques to avoid government retaliation.

At the university level, Suharto imposed this form of oppression through a "normalization policy," (Normalisasi Kehidupan KampusNKK) which sought to depoliticize campus life by restricting the activities of student organizations and requiring students to focus entirely on their studies. In order to sufficiently depoliticize campus life, the government introduced the concept of the three duties of tertiary educational institutions: expertise, responsibility and corporateness. Moreover, it replaced independent student bodies and university student councils with administration-dominated "activity coordination bodies" and prohibited Islamic student organizations from conducting their activities on campus; only the coordination bodies were permitted to represent the students. This strategy was also applied to social organization and become an effective measure to exclude Islamic organizations from political participation and an important mechanism of the state and the military's management and

\footnotetext{
${ }^{11}$ Liddle, Leadership, p. 611; Porter, Managing, p. 39.

12 The five principles of the Pancasila are belief in one god, humanitarian justice, unity of Indonesia, democracy by deliberation and consensus, and social justice for all.

13 Porter, Managing, p. 39.

14 Ibid.
} 
supervision of society as well as vehicles for the controlled mobilization of Indonesian people into state-guided political and economic projects. ${ }^{15}$

Besides "the normalization" policy of student life in university campuses and depoliticizing the Muslims, the New Order of Suharto attempted to shape Indonesian Islam so that it was supportive of government development programs. He utilized Muslim intellectuals to legitimize the program by quietly giving approval to an Islamic Renewal (Pembaruan) movement led by Nurcholish Madjid, the president of the National Organization of Islamic Students (Himpunan Mahasiswa Islam or HMI) and Harun Nasution, the Rector of State Institute of Islamic Studies, IAIN). The most crucial concept in Madjid's Islamic political viewpoint was that of secularization, ${ }^{16}$ while in Nasution's it was that of rationalization. In line with his secularization concept, in 1970 the former provoked heated controversy when he called for Islam to be separated from politics with the slogan "Islam Yes, Islamic Parties No."17 The Renewal movement emphasized the interpretation of scripture in application to the modern world and the realization of Islamic values in personal life rather than through political parties.

Madjid's slogan, which he claimed to be a real depiction of Muslim society in Indonesia, was more imaginary than reality. In fact, the Islamic organizations responded to the Suharto regime's policies in a variety of ways. Muslim thinkers adopted a flexible approach weaving between official suspicion of Islam and the conservative tendencies of ulama. Some key dakwah groups, most notably Mubammadiyah and Nabdlatul Ulama (NU) chose to depoliticize and withdraw from politics

\footnotetext{
15 Ibid., p. 33; 57.

16 The idea was proclaimed after his short visit to the United States, in the late 1960s. After a year or two Madjid proclaimed that Islam is secular religion and offered the concept secularization (sekularisasi) in the religious life of Muslims. The concept that he claimed to be his own was duplicated from Harvey Cox's concept of secularization in his renowned work The Secular City, the most popular book in the US in the late 60s. The book is Cox's attempt to prove that Christianity is in line with modernity, a point that Madjid took to support the government development program.

17 Nurcholish Madjid's speech was entitled, "Keharusan Pembaruan Pemikiran Islam dan Masalab Integrasi Umat" [The Necessity of Renewing Islamic Thought and the Problem of the Integration of the Islamic Community]. An English translation of the speech can be found in Charles Kurzman, (ed.), Liberal Islam: A Sourcebook (Oxford: Oxford University Press, 1998), pp. 284-9.
} 
to focus on education and social welfare concerns. Other Islamists compromised their own beliefs to attain government sanction, but this did not diminish their popular support. Since they were unable to promote a political Islamist dogma, many Islamic scholars would hide their ideas in notions of social welfare. ${ }^{18}$

On the other hand, the Suharto regime, in the early 1990s, adopted a program to send lecturers of Islamic higher educations to western centers of Islamic studies in Canada, the United States and the United Kingdom. This was to steer them away from the main centers in the Middle East, ${ }^{19}$ and at the same time to disseminate liberal thought among Muslim intellectuals. This program was quite instrumental in enhancing the rise liberalism in the future. This phenomenon will be dealt with later.

The second period of Suharto regime was marked by a strategy of political openness. In order to seek to ward off challenges to his rule, Suharto drew on support from incorporated Muslim interests. This led to a state-Islamic accommodation and a simultaneous regime-initiated political opening through which Islamic groups remobilized after two decades of regime-enforced depoliticization. With the Islamic revival, Suharto saw an opportunity to play the Islam card against members of the military and civilian elites who might challenge his rule. ${ }^{20}$ The major action Suharto took during this period was his sanctioning of the formation of the Association of Indonesian Muslim Intellectuals (ICMI), in December 1990. This was an organization comprised of Muslim intellectuals, bureaucrats and activists, both pro- and antimilitary, both pro- and anti-Suharto. The association was chaired by the Minister of Research and Technology B.J. Habibie, with Suharto as its patron. However, ICMI was never meant to be an autonomous organization democratically representing the political interests of Indonesian Muslims to their government. Instead, it was a state corporatist organization, dominated by high officials closely allied with President Suharto, whose main policy slogan was one of human resource development and whose chief political enemies were neither radicals nor Christians, but market-oriented economists. ${ }^{21}$

\footnotetext{
18 Vatikiotis, Indonesian, p. 129; Hefner, Civil Islam, p. 121.

19 Vatikiotis, Indonesian, p. 127.

${ }^{20}$ Porter, Managing, p. 4; Hefner, Civil Islam, p. 121.

${ }^{21}$ Liddle, Leadership, p. 625.
} 
Suharto's political openness, drawing on support from incorporated Muslim interests, also brought about an increase in santri participation in the Suharto administration. Accordingly, when Habibie ascended to the Presidency of Indonesia in May 1998, following Suharto's resignation in the aftermath of the anti-Chinese riots, leading Muslim activists were appointed to key positions in Habibie's administration..$^{22}$

As a result of this short period of political openness, roughly from 1990-1994, myriad Islamic groups remobilized and Islamic political leaders, such as Abdurrahman Wahid, began openly criticizing the state. $^{23}$ This brief window of political tolerance, followed by a repressive clampdown on political activism, had an unintended consequence: it raised people's expectations for change. Not surprisingly, Islamic student organizations were at the forefront. Mosques served as the main organizing centers because they permitted students to organize activities out of the purview of the state and its corporatist institutions. In other words, the state could not control the Islamic organizations. By 1996, the diverse array of Islamic organizations and oppositional activity had grown intolerable for the Suharto regime and they turned back to repressive policies. ${ }^{24}$

In sum, the strategy of using indiscriminate repression and targeting Suharto's enemies rather than dangerous groups initiating disturbances did not succeed in demobilizing the Islamic organizations. It even brought about the rise of Islamic political movements. Because the regime limited political participation, Muslims were driven to form underground organizations with informal networks, employing cell structures to escape the watchful eyes of the state. These organizations were widely formed in university campuses throughout Indonesia. Therefore, by 1998, when the autocratic leader, President Suharto

\footnotetext{
${ }^{22}$ For a discussion of the transition from Soeharto to Habibie, see Leo Suryadinata, "A Year of Upheaval and Uncertainty: The Fall of Soeharto and the Rise of Habibie," Southeast Asian Affairs (Singapore: Institute of Southeast Asian Studies, 1999), pp. 111127. Soeharto's overtures to the Muslim community is covered in Robert W. Hefner, "Islam, State, and Civil Society: ICMI and the Struggle for the Indonesian Middle Class," Indonesia No. 56 (1993): pp. 1-35 and R. William Liddle, "The Islamic turn in Indonesia: A Political Explanation," the Journal of Asian Studies, 55, no. 3 (August 1996): pp. 613-634.

${ }^{23}$ Hefner, Civil Islam, p. 162.

${ }^{24}$ Porter, Managing, p. 172; pp. 198-199.
} 
stepped down from power, some Muslim groups were at the forefront of demands for democracy.

\section{The Impact on Student Movements}

The global political situation and the oppressive depoliticization strategy applied by Suharto regime described above brought about consequences. According to Tilly's theory, repression can raise collective action among the opposition, ${ }^{25}$ and such actions as riots, rebellion and revolution may target government agents. ${ }^{26}$ Meanwhile, Tarrow assumes that the outcome of repression in authoritarian systems can either demobilize or radicalize collective action. ${ }^{27}$ The theories of Tilly and Tarrow were proven in the emerging riots and protests of people power in the Reformation Era, prior to the resignation of Suharto in 1998 that later on became social and political movements. However, for Muslims, social and political movements were driven not only by political oppression but also by religious obligation, that to study Islam and to teach it to others as well as to practice it in daily life are parts of Islamic dakwah. In addition, the national and international situation played a pivotal role in influencing the students minds.

Now, we shall trace the consequences of both the international situation and Suharto's oppressive policy on student life and thought.

These activities were the embryo of the Islamic movement that subsequently became the one mobilization vehicles of Islamic political parties.

The impact of the "Normalization of Campus" policy was the shift of political activity to the dakwah movement. Muslim students movements were not depoliticized easily; many went underground and mosques became the new foci of politico-religious activities and discussion groups that helped to fuel the Islamic awakening. ${ }^{28}$ Student centers became quiet and all the activity was channeled to the

\footnotetext{
${ }^{25}$ Charles Tilly, From Mobilization to Revolution (Reading Massachusetts: Addison-Wesley Publishing, 1978), p. 100.

${ }^{26}$ Charles Tilly, Politics of Collective Violence (Cambridge: Cambridge University Press, 2003), p. 28.

27 Sidney Tarrow, Power in Movement: Social Movements and Collective Action in Politics (Cambridge: Cambridge University Press, 1994), p. 92.

28 Porter, Managing, p. 2; Liddle, Leadership, p. 157; p. 624.
} 
mosque. ${ }^{29}$ "People need a channel for their political aspirations and they will find it where they can" says Rizal Ramly, former student of ITB, Bandung. ${ }^{30}$ All activities in the mosque were operated underground or with a low profile. In the late 1970s the study of Islam was influenced by the spirit of the Iranian Revolution, ${ }^{31}$ but not of the Shiite school of thought. The spirit of Islamic revival was so great that many students became curious to learn about Islam. In Salman Mosque, for example, students were inspired by the fiery sermons of Imaddudin. At Salahuddin Gajah Mada University Amin Rais, Syaifullah Mahyuddin and others were important figures of student dakwah activities, at Airlangga University in Surabaya, Dr. Fuad Amsyari was the most prominent figure. The dakwah movement quickly spread to mosques of other universities, where Qur'an study groups were established. Therefore, the terms employed for naming their study group were usroh (nuclear family), halaqah (a circle of students and their teacher), and tarbiyah (education under a teacher who provides moral guidance). The subject matter focused primarily on inculcating religious morality for those who had no background of Islamic studies. However, it developed into politic and civil society studies.

In the 1980s, university mosques or mosque around the universities became the center of Islamic learning of secular universities. ${ }^{32}$ Although the groups that were part of this movement

${ }^{29}$ Salman mosque at ITB Bandung, Salahuddin mosque at Gajah Mada University of Jogjakarta, and Arif Rahman Hakim mosque at University of Indonesia in Jakarta, are few examples of university mosques.

30 This refers to the statement of an economist Rizal Ramli when he was student of ITB Bandung, as quoted by Elizabeth Fuller Collins, Fulbright Visiting Fellow Universitas Islam Negeri Syarif Hidayatullah in his unpublished paper Dakwah and Democracy; The Significance of Partai Keadilan and Hizbut Tabrir.

31 Ali Syariati (1933-1977) was the most influential intellectual leader of the Iranian Revolution. He had studied in France and was influenced by Third World and Left intellectuals such as Jean-Paul Sartre, Che Guevarra, and Frantz Fanon (Kepel 2002, 37-8). He transposed Marxist language of class struggle into an Islamic vocabulary, distinguishing the mostakbirine (the arrogant) and the mostadafine (the disinherited or oppressed).

32 See V.S. Naipaul, Among the Believers: An Islamic Journey (London: A. Deutsch, 1981) for a description of a dakwah session at Salman Mosque and Beyond Belief: Islamic Excursions Among the Converted Peoples (New York: Random House, 1998). The usrob movement was strong in the Syuhada Mosque and the Shalauddin mosque at Gadjah Mada University in Yogyakarta and the Arif Rahman Hakim Mosque at the University 
did not relate themselves with political activities, they were mostly of the opinion that the government was corrupt and unjust. Internationally they also shared the view that westernization and secularism were going on throughout the Muslim world and should be prevented. Nevertheless, their spirit to learn and practice Islam was so great that they were open to any idea or school of thought brought by their tutors.

While university students were actively involved in studying Islam from whatever sources they could find, students returning to Indonesia after studying in the Middle East provided new leadership to the dakwah movement. Various ideas and thoughts were brought home by the graduates of Middle East Universities. They can be categorized into at least four streams.

The first stream was the thought of the Muslim Brotherhood (Ikhwaral-Muslimur. It is the best known political movement in Egypt. The works Hassan Al Banna, Mustafa Masyhur, and Sa'id Hawwa were translated into Bahasa Indonesia and became the core texts of dakwah activists.

A second stream of dakwah represents the Salafy school of thought ${ }^{33}$ of Saudi Arabia. This stream was initially used to prevent the influence of revolutionary Shiism from Iran. The study group that focused on Salafy school of thought was concentrated at Universitas Indonesia, IKIP Jakarta (Now become Jakarta State University), Universitas Trisakti, and other Jakarta institutions of higher learning.

Later this group established an institute for dakwah development, Lembaga Pengkajian dan Pengembangan Dakwah (LPPD), to extend the reach of dakwah from university campuses to neighboring mosques in areas such as Jabotabek, the industrial zone around Jakarta.

of Indonesia in Jakarta. See John Malcolm Brownlee, "Scripturalism and Religious Liberalism on Yogyakarta Campuses," (Unpublished MA thesis, Ohio University, 1997).

33 Wahhał Islamic reform movement in Saudi Arabia. Salafy, which refers to devout ancestors or to the Prophet and his companions or the first pious generation, is an Islamic movement of the second half of the 19th c. inspired by the writings of the Sayyid Jamal al-Din al-Afghani (1838-1897) of Persia, the Egyptin Muhammad Abduh (18491905), and the Syrian Rashid Rida (1865-1935). Salafy teachers also draw on the teachings of Ibn Taymiyyah (1268-1328), who distinguished between the realm of Islam and the realm of jahiliyyah (a state of ignorance or barbarism) and called for jihad against the "un-Islamic" Muslim rulers. 
In the 1990s this group extended its activities to Kalimantan, Riau, NTT, and Irian Jaya, utilizing the network of Dakwah Institutions for Campuses (Lembaga Dakwah Kampus or LDK) graduates who went to work in different parts of Indonesia.

Hizbut Tahrir (HT) is yet a third stream of dakwah that was established in Indonesia in the 1980s. ${ }^{34}$ Hizbut Tahrir was introduced to Indonesia by Abdurrahman Al-Baghdadi, the leader of Hizbut Tahrir in Australia, who moved to Bogor at the invitation of $\mathrm{KH}$ Abdullah bin Nuh, the head of Al Ghazali Pesantren. The movement spread from the Bogor Agricultural Insitute (Insitut Pertanian Bogor or IPB) to other universities in Java (Padjadjaran University in Bandung, IKIP Malang, and Airlangga University in Surabaya) and to Hasanuddin University in Makassar through the LDK movement. Until the fall of Suharto, Hizbut Tahrir was almost an underground movement. Few reports of their activities appeared in the media until 2001. Hizbut Tahrir claims to have 100,000 members with divisions in every province. Sidney Jones notes that HT has grown more rapidly than other radical Islamic groups, particularly in certain locations, such as South Sulawesi. ${ }^{35}$

Hizbut Tahrir (HT) emphasized an educational (or moral) movement. The aim of dakwah was to show that Islam provided a solution to the multiple problems that confronted society. They also believed that Islamic societies would become strong and respected if syariah law were established. The vision of establishing a khilafa (chaliphate) was both a source of strength and weakness to the movement. Many young people were attracted to HT because of its revolutionary ideal and the argument that Islam was no longer a

\footnotetext{
34 Hizbut Tahrir (also transcribed Hif́b ut-Tahri was founded in 1953 by Sheikh Taqiyuddin An-Nabhahani (also transcribed Taqi 1953. Nabhahani was a member Muslim Brotherhood (al-Ikhwa $\gg$ al-Muslimum, who was ousted from the movement for his views. He argued that Shari (Islamic law) was the key to restoring the greatness of Islamic civilization. In his view the focus on ethical teaching of Islam that typified the Muslim Brotherhood and other dakwah movements drained energy away from the political struggle: "The passions of the ummah have been defused by these boring, cheap and repetitive discourses . . Nations are not [judged] by morality or ethics but by the faiths they embrace and the ideas they adopt and the systems they implement." Translation by Azzam Tamimi, "Hizbut-Tahrir Reflections on its origin and its ideas," http://www.ii-pt.com/web/papers/tahrir.htm.

35 Sadanand Dhume, "Hizbut Tabrir Using War in Iraq to Seek Converts," Far Eastern Economic Review, April 3, (2003).
} 
powerful force in world politics because Muslims had been divided by a nation-state system and democracy imposed by the West. For them, democracy as a Western form of government, was rejected, and involvement in the politics of a secular state was regarded as a useless diversion, therefore its members were not allowed to get involved in the current political system. It was for this rejection of the nation-state and democracy that Hizbut Tahrir could be considered the most revolutionary stream of dakwah, yet the movement still operated within democratic parameters and no subversive action against the government was taken. Unlike Salafy and other dakwah activists, their concern with studying Islamic thought was particularly serious. Critics, however, found the goals of Hizbut Tahrir unrealistic.

In fact, it was Hizbut Tahrir that initiated the establishment of a network of dakwah activists from the university campuses of LDK. LDK held its first gathering (Silaturahmi) in 1988. In the 1990s the LDK conducted regular recruitment campaigns among incoming students. By the early 1990s, most of the LDK were led to form the Indonesian Muslim Student Action Union (Kesatuan Aksi Mabasiswa Muslim Indonesia or KAMMI), the organization of Islamic students in support of the Reformasi movement to bring down Suharto. Both HT and KAMMI agreed on the long term goal to apply Islamic values to the state, but they differed in their views of the appropriate strategy. For HT the application of syariah would impose Islamic values on society in a top down strategy. KAMMI adopted a bottom-up strategy of Islamization in which the party would attract support through its adherence to Islamic values and come to power through democratic means.

The fourth stream was the Association of Inter-Campus Muslim Student Activists, which is abbreviated into HAMMAS. HAMMAS, which was established in October 1998 shortly after the fall of Suharto, claimed to have 10,000 members in August 1999, but this was most probably an over-estimate of its true strength. The name HAMMAS, chosen to declare militant support for Palestinians, reflects the militant and radical orientation of this stream of the dakwah movement.

These organizations were established by a younger generation of Muslim students at secular universities, who came to maturity in the 1980s and 1990s. They were disillusioned with the promise of the secular nation state to bring prosperity and greater social and economic justice. However, most of the above dakwah activists at campuses had 
no Islamic studies background except for learning activities in their study group during their free time of academic programs. Since most of them were not students of Islamic universities, the subject matter in their study groups was not as sophisticated as in the groups of those who studied at Islamic higher educations, yet their determination to practice Islam in their daily life was strong. However, at Islamic university campuses the contrary, applied. There were major tendencies to learn and adopt modern Western thought and ideologies. At Indonesia Islamic University (UII) and the State Institute of Islamic Studies (IAIN) Yogyakarta, for example, groups of students were having intensive studies on communism, socialism, capitalism, secularism and other Western thought.

Several points are worth noting here. Political oppression towards university students by the New Order regime was generally not effective. Instead, it became a vehicle for Muslim student mobilization. The embryos of the Islamic movement came not from Islamic university campuses, like IAIN and other Islamic universities or institutes. For this phenomenon Hefner provides several answers 1) there was an increase in literacy, which made studying and adherence to Islamic customs and practices more likely, 2) the official state education curriculum had a religious component to it so more people were exposed to formal religious ideas; 3) participation in organized religion was a relatively safe outlet for expression and it was a sphere of life not totally controlled by the state. In fact, by this time, there was even some space for religious groups to influence public policy. ${ }^{36}$ However, it is no easy to explain why the existing study groups of the HMI (Muslim Student Association) and PMII (Indonesian Muslim Student Movement) played no significant role in the above student movements. Perhaps, the most likely explanation was that the HMI accepted Pancasila as the basis of their association, which implied that the association was already under the control of the New Order government.

\section{The Impact on Political Movements}

The impact of political oppression and depoliticization of Muslim organizations is another interesting point to note. From the study group or dakwah activities at university campuses the student activities

${ }^{36}$ Hefner, Civil Islam, p. 16. 
were steered toward political movement. Among the first political movements that stemmed from dakwah activities at university campuses were the Partai Keadilan ${ }^{37}$ and Hizbut Tahrir. The former was prepared to participate in the democratic process, whereas the latter refused to join such a political process because it came from the West. Another political party that arose from Islamic organizations (or parties) in the past was the Crescent and Star Party (Partai Bulan Bintang), which derived its ideas from Masyumi, the Islamic political party that was banned by Sukarno in 1960. Other parties established by Muslim intellectuals and clerics but adopting a secular platform were the Nation Awakening Party (PKB) and the National Mandate Party (PAN). In a free democratic parliamentary election in June 1999, fortyeight parties competed for 462 contested seats of which Islamic parties gained 163.38

Of those political movements the Justice Party (Partai Keadilan, PK) was perhaps the most sophisticated and promising Islamic party. It was set up shortly before the 1999 general elections. Several of its leaders were educated in the United States, Europe and the Middle East, among them. Nurmahmudi Ismail, the first President of the party, who was a graduate of Texas A\&M University. He was later to become the Minister of Forestry in Abdurrachman Wahid's administration. As we mentioned above, this party emerged from university student activities in various campuses since the 1980s. PK campaigners in 1999 stressed not the Islamic state but opposition to official corruption, their professional qualifications to govern, and an egalitarian economic policy balancing phased industrial development with self-sustaining agricultural growth. PK's platform also proposed a sharper separation of executive, legislative, and judicial powers, with a Supreme Court no longer appointed by the president. The New York Times, 30, April, 2002, took keen interest in the emergence of the Justice Party, especially in its mission to "restore a moral focus in a country that has fallen in chaos and widespread corruption", ${ }^{39}$ based on shariah (Islamic law).

\footnotetext{
${ }^{37}$ Partai Keadilan is now known as Partai Kedilan Sejabtera (Justice and Welfare Party).

38 What is meant by Islamic political parties could be Islam-base parties like PKS and $\mathrm{PBB}$ or parties established by Muslim leaders and supported by Islamic organization, like PKB and PAN.
}

39 New York Times, 30 April 2002. 
Though their basic approach to Islam was moderate, many PK activists did not have roots in any of the pre-existing modernist organizations, such as Muhammadiyah or the DDII (Dewan Dakwah Islamiyah Indonesian). PK thus represented something new in Indonesian politics. Most of the party's voters were urban and were concentrated particularly in the neighborhoods around major universities, where many PK leaders were lecturers and researchers. In its first participation in the 1999 parliamentary vote, PK gained 1.4 percent of the vote ( 7 seats) but increased significantly in the 2004 election to 7.3 percent, (45 seats).

PKB (Nation Awakening Party) was founded in 1998 by the preeminent NU leader, Abdurrahman Wahid. PKB received 12 percent of the 1999 parliamentary vote (51 seats), but only 10.57 percent in 2004 parliamentary vote (52 seats). Though founded by NU and supported by Muslim traditionalists, PKB's formal ideological base is not Islam but Pancasila, ${ }^{40}$ adopting secularist policies in government. Membership of the party is open to non-Muslims, but few have joined. At the October 1999 session of the People's Consultative Assembly Abdurrahman Wahid was elected as President of Indonesia by a coalition led by "Muslim" parties and leaders. ${ }^{41}$ Wahid's presidency was seen as the first democratic transfer of power in Indonesian history. ${ }^{42}$ However, twenty months later, Wahid had been widely condemned as a failed leader. On July 23, 2001 he was impeached by the congress because of his inability to address continuing corruption at the highest levels, economic disorder, and separatist movements. ${ }^{43}$

\footnotetext{
40 The famous Indonesian five principles of Pancasila was first enunciated by Sukarno in 1945.

41 General Election Commission of Indonesia, Analyzing Indonesia's Election, 1999 (Jakarta: Indonesian General Election Commission, 2001). See also, Dwight King, Half-Hearted Reform: Electoral Institutions and the Struggle for Democracy in Indonesia (Westport, CT: Praeger, 2003), see chapters 3 \& 4 on the 1999 elections.

42 It was through the support his party that Abdurrahman subsequently became Indonesia's first democratically elected president defeating Megawati Soekarnoputri of PDI-P during the 1999 MPR session to vote president, serving from October 1999 to July 2001, MPR, Majelis Permusyawaratan Rakyat or People's Consultative Assembly, a kind of super-Parliament whose responsibilities until very recently included selection of the president and vice-president..

43 Greg Barton, Gus Dur: The Authorized Biography of Abdurrabman Wabid (Jakarta: Equinox Publications, 2002).
} 
Wahid had a reputation within Indonesia as a liberal thinker with a pluralistic outlook. It was probably due to this outlook and his authoritative approach that Wahid was defeated by Hasyim Muzadi in the election of the Chairman of NU at Boyolali in 2004 and by Muhaimin Iskandar in the internal dispute of PKB recently.

Another Islamic party was The Crescent and Star Party (Partai Bulan Bintang, PBB). Established in 1999, and campaigning for an Islamic state, many of its leaders had family connections with Masyumi leaders of the 1950s. Given its tiny vote ( 2 percent $=13$ seats in 1999 and $2.62=11$ seats in 2004), compared to Masyumi's 21 percent in 1955 , PBB was considered by most observers to be a party of the past.

Another party established during the New Order regime and supported by traditionalist Muslims was PPP (Unity Development Party). With Islam as its ideology, PPP won 10 percent of the 1999 vote (46 seats), but gained a lower percentage in the 2004 election $(8.15$ percent) at the same time, increasing its number of seats to 58 .

Another new party set up by Muslim activists was PAN (National Mandate Party). It was founded and led by Amien Rais, ${ }^{44}$ in 1998, and like PKB, PAN was founded as an open party with Pancasila as its ideology, and closely identified with modernists. Like Wahid, to attract both liberal or moderate Muslims and non-Muslims Amien Rais appeared to be committed to a pluralist vision. Nonetheless, the party failed to attract many liberal Muslims and non-Muslims. In 1999 PAN got only 7 percent of the vote. The party cultivated only Muhammadiyah and other modernist voters, while Amien Rais was defeated in the first round of presidential election. In the 2004 election, PAN's share of the vote decreased form 7 percent to 6.44 percent, but its number of seats increased from 34 to 52 . For the ideological basis of some prominent parties in Indonesia and their vote result from 1955, 1999 and 2004 election see table 1.

Although most of the parliamentary seats in the 1999 election were still dominated by the old parties established during Suharto regime, ${ }^{45}$

\footnotetext{
44 Amin Rais is an American-educated professor of international relations, who later on chaired the MPR In the 1990s Amien headed Muhammadiyah, the largest Muslim modernist social and educational organization. He is still the most prominent Muhammadiyah personality and modernist politician.

45 The seat gained by PDI-P (Indonesian Democracy Party-Struggle), was 34 percent of the vote and 153 seats; Golkar, was 22 percent of the vote and 120 seats; PPP (Development Unity Party), was 10 percent and 58 seats.
} 
Islamic political parties still gained almost 35 percent of the total seats. In the 2004 election the seats of Islamic parties increased significantly, while the secular parties got fewer votes, except Partai Demokrat, PD (Democrat Party), the party that brought Susilo Bambang Yodhoyono to the Presidency.

Table 1: Indonesia's Democratic Elections 1955, 1999 and 2004.

\begin{tabular}{|c|c|c|c|c|c|c|c|}
\hline 1955 Election & $\%$ & 1999 Election & $\%$ & Seats & 2004 Election & $\%$ & Seats \\
\hline $\begin{array}{l}\text { PNI; } \\
\text { (Nationalist/ } \\
\text { Sukarnoist } \\
\text { ideology) }\end{array}$ & 22 & $\begin{array}{l}\text { PDI-P; } \\
\text { (Nationalist/ } \\
\text { Sukarnoist } \\
\text { ideology) }\end{array}$ & 34 & 153 & $\begin{array}{l}\text { PDI-P; } \\
\text { (Nationalist/ } \\
\text { Sukarnoist } \\
\text { ideology) }\end{array}$ & 18.53 & 109 \\
\hline $\begin{array}{l}\text { Masyumi; } \\
\text { (Islamic } \\
\text { ideology, mass } \\
\text { base modernist } \\
\text { and } \\
\text { traditionalist } \\
\text { Muslim) }\end{array}$ & 21 & $\begin{array}{l}\text { Golkar; } \\
\text { (Universalist } \\
\text { ideology, but } \\
\text { mass } \\
\text { predominantly } \\
\text { modernist } \\
\text { Muslim) }\end{array}$ & 22 & 120 & $\begin{array}{l}\text { Golkar; } \\
\text { (Universalist } \\
\text { ideology, but } \\
\text { mass predomi- } \\
\text { nantly } \\
\text { modernist } \\
\text { Muslim) }\end{array}$ & 21.58 & 128 \\
\hline $\begin{array}{l}\text { NU or } \\
\text { Nahdlatul } \\
\text { Ulama; } \\
\text { (Islamic } \\
\text { ideology, mass } \\
\text { base } \\
\text { traditionalist } \\
\text { Muslim) }\end{array}$ & 19 & $\begin{array}{l}\text { PKB; } \\
\text { (Universalist } \\
\text { ideology but } \\
\text { mass } \\
\text { predominantly } \\
\text { NU, } \\
\text { traditionalist } \\
\text { Muslim) }\end{array}$ & 12 & 51 & $\begin{array}{l}\text { PKB; } \\
\text { (Universalist } \\
\text { ide ology but } \\
\text { mass } \\
\text { predominantly } \\
\text { NU, } \\
\text { traditionalist } \\
\text { Muslim) }\end{array}$ & 10.57 & 52 \\
\hline \multirow[t]{2}{*}{$\begin{array}{l}\text { PKI; } \\
\text { (Communist } \\
\text { ideology, mass } \\
\text { base } \\
\text { syncretist/non } \\
\text {-Muslim) }\end{array}$} & 17 & $\begin{array}{l}\text { PPP; } \\
\text { (Islamic } \\
\text { ideology, } \\
\text { traditionalist } \\
\text { and modernist } \\
\text { Muslim) }\end{array}$ & 10 & 58 & $\begin{array}{l}\text { PPP; } \\
\text { (Islamic } \\
\text { ideology, } \\
\text { traditionalist } \\
\text { and modernist } \\
\text { Muslim) }\end{array}$ & 8.15 & 58 \\
\hline & & $\begin{array}{l}\text { PAN; } \\
\text { (Universalist } \\
\text { ideology, but } \\
\text { mass } \\
\text { predominantly } \\
\text { modernist } \\
\text { Muslim) }\end{array}$ & 7 & 34 & $\begin{array}{l}\text { PAN; } \\
\text { (Universalist } \\
\text { ideology, but } \\
\text { mass } \\
\text { predominantly } \\
\text { modernist } \\
\text { Muslim) }\end{array}$ & 6.44 & 52 \\
\hline
\end{tabular}




\begin{tabular}{|c|c|c|c|c|c|c|c|}
\hline & & $\begin{array}{l}\text { PBB; } \\
\text { (Islamic } \\
\text { ideology, mass } \\
\text { modernist } \\
\text { Muslim, } \\
\text { successor to } \\
\text { Masyumi) }\end{array}$ & 2 & 13 & $\begin{array}{l}\text { PBB; } \\
\text { (Islamic } \\
\text { ideology, mass } \\
\text { modernist } \\
\text { Muslim, } \\
\text { successor to } \\
\text { Masyumi) }\end{array}$ & 2.62 & 11 \\
\hline & & $\begin{array}{l}\text { PK; } \\
\text { (Islamic } \\
\text { ideology, mass } \\
\text { base Muslim } \\
\text { but neither } \\
\text { modernist nor } \\
\text { traditionalist) }\end{array}$ & 1 & 7 & $\begin{array}{l}\text { PKS; } \\
\text { (Islamic } \\
\text { ideology, mass } \\
\text { base Muslim } \\
\text { but neither } \\
\text { modernist nor } \\
\text { traditionalist) }\end{array}$ & 7.34 & 45 \\
\hline & & & & & $\begin{array}{l}\text { PD; } \\
\text { (Democratic } \\
\text { Party, secular, } \\
\text { nationalist) }\end{array}$ & 7.5 & 57 \\
\hline & & & & & $\begin{array}{l}\text { PDS; } \\
\text { (Christian } \\
\text { Ideology) }\end{array}$ & 1.60 & 12 \\
\hline $\begin{array}{l}\text { All other } \\
\text { parties } 21\end{array}$ & 21 & $\begin{array}{l}\text { All other } \\
\text { parties }\end{array}$ & 12 & & $\begin{array}{l}\text { All other } \\
\text { parties }\end{array}$ & 24.77 & 26 \\
\hline Total & 100 & Total & 100 & 462 & Total & 100 & 550 \\
\hline
\end{tabular}

The phenomenon of the rise of Islamic political parties with an increased number of parliamentary seats from 1999 to 2004 suggests that the claim of neo-modernist liberal Muslim figure Nurcholish Madjid in early 70s "Islam yes Islamic party no" is no longer tenable. The statement was apparently intended to entertain the New Order government whose strategy was to depoliticize Muslim society. In fact, in the free democratic elections Muslims' participation in political parties was manifest. There might be various factors involved in the rise of new Islamic base parties. It could be the outcome of the longsuppressed political aspiration of Muslim society by authoritarian rule to enjoy space granted to them by democratic freedom. Another explanation, especially for the success of the PKS, was its campaign on a platform of good governance based on Islamic moral values. This 
point was well-directed at a time when, for many people, the fundamental problem of government administration was cultural and moral weakness. The intrusion of the materialistic worldview of Western civilization into the Indonesian middle class brought about an incessant series of corruption cases in the government administration. The experience of other countries suggested that a state incapable of bringing about justice and prosperity was the best breeding ground for primordial sentiment, including Islam, to emerge. Unless the issue of social justice were addressed adequately, the spirit of radicalism that emerged from Muslims, non-Muslims or secularist Muslim activists would always challenge the government. In short, the advent of the "Justice and Welfare Party" (PKS), was welcomed by Indonesian people. It was known not only as an Islamic political party but also as a party with self-discipline, a gradual, peaceful approach to meeting reformist goals and commitment to end corruption. It also planned to be a pioneer in upholding Islamic values within a framework of national unity and integrity. Party activists, such as Hidayat Nur Wahid and Zulkiflimansyah, stated:

We must work hard to ensure the real voice of Islam is heard in Indonesia and even in the world at large. We must speak out boldly in defense of a dynamic, moderate Islam—an Islam that upholds the sanctity of human life, reaches out to the oppressed, respects men and women alike, and insists on the fellowship of all humankind. Such is the true Islam of the Prophet, we believe, that some are now seeking to destroy." ${ }^{\prime 4}$

Unfortunately, many observers interpreted the rising tide of Islamic politics as a sign of Islam's challenge to democracy or the rise of fundamentalism in politics. This interpretation may be deemed biased. So far those parties were still within the democratic sphere and had committed no political fraud. The rising Islamic tide should, therefore, be understood in terms of the democratic framework, since in the reformation era every citizen had a full right to participate in democracy regardless of his or her religion, race and ethnic group. Justice and Welfare Party (PKS) and other Islamic parties had a commitment to participate in democratic elections and bound

\footnotetext{
46 Hidayat Nur Wahid and Zulkiflimansyah, "The Justice Party and Democracy: A Journey of a Thousand Miles Starts with a Single Step," Asia Program Special Report, no 110 (April 2003), p. 20.
} 
themselves to the democratic process, therefore there was no reason to suspect the outcome of the democratic process, or to refuse to acknowledge the democratic victory of an Islamic party, should that occur. Such a reaction would have risked the very principles of democracy, and would have been seriously counterproductive to the promotion of democracy.

On the other hand, Islamic movements, like PKS, were challenged to shift from slogans to programs. They were required to maintain a balance between social activism and intellectual activism, and were urged to elaborate whole Islamic concepts, especially those which were urgently required by the current situation, such as tolerance, human right, justice, welfare and the like. They were required to become more self-critical, and speak out against un-Islamic practices in political and social affairs, both at national and international level, including corruption, oppression, acts of terrorism by extremists, and others.

\section{The Current Religious Cleavage}

The current political situation and its future could be best understood from an Islamic worldview by which we may sketch the position of every group in relation to Islam and to the Indonesian political setting. To deal with religious movements presupposes the understanding of religion, which is generally defined as a system of belief. A system of belief or religion can be seen as a mental phenomenon, dealing with the matter of believing, or a social phenomenon, concerning a feeling of belonging. ${ }^{47}$ However, in the present situation, a system of belief can be best seen as worldview. It is an integrated system of basic beliefs about the nature of ourselves, reality, and the meaning of existence. ${ }^{48}$ It is also defined as a belief, feeling and thought that functions as a motor of social and moral change. ${ }^{49}$

To see Islam from a worldview perspective is to see the whole concept of Islam as system of belief and of social life. As a system of

47 Kenneth D. Wald and C. D. Smidt, "Measurement Strategies in the Study of Religion an Politics," in David C. Leege (eds), Rediscovering the Religious Factor in American Politic (Aemonk, N.Y: R.E. Sharpe, 1993), p. 32.

48 Thomas F Wall, Thinking Critically About Philosophical Problem, A Modern Introduction (Wadsworth, Australia: Thomson Learning, 2001), p. 532.

49 Ninian Smart, Worldview, Cross Cultural Explorations of Human Belief (New York: Charles Sribner's sons, n.d.), pp. 1-2. 
belief it embraces the belief that God's revelation is preserved in the Qur'an, and that Muhammad's words and deeds were collected in narrative reports or hadith attributed to the Prophet. The system of social life is to be found in these two sources of the Islamic worldview. Much of the content of the Qur'an concerns not only guidelines for worship, but also regulations governing marriage, inheritance, business contracts, criminal punishment, and the conduct of war. It is plausible therefore, that Prophet Muhammad was not only a religious leader, but also a chief executive, judge, and commander in-chief of the Medina state. He is he role model for Muslims, representing the all-embracing nature of the Islamic worldview. As a worldview, Islam provides guidelines for private and public lives, duties to God and duties to society. In Islamic civilization, religion occupies an important place in public life: in the ideology of state and its institutions and in the conduct of politics. Islam is incompatible with secularism or a secular worldview. Ideologically, the Islamic community (ummah) was a religio-political state or empire. Muslim rulers (caliphs or sultans), as Muhammad's successors as head of state, were to assure government according to Islam and to spread and defend Islamic rule. ${ }^{50} \mathrm{In}$ addition, Islam also gives full protection to other religions. They are permitted to practice their religion, to be governed by their own religious leaders, laws and courts, and they are also protected by Muslims from external aggression. No oppression or compulsion towards adherents of other religions to embrace Islam is allowed. Islam has developed ways to deal with other religions since it has a rich experience of living with other traditions, beliefs and religions. All these principles were practiced during the golden age of Islamic civilization from $7^{\text {th }}$ until $19^{\text {th }}$ century.

There was, however, an essential modification in the understanding Islam due to the orientalist tradition of studying Islam. Likewise, a fundamental change in the practice of Islamic teaching took place under the pressure of colonialism. Esposito conspicuously states:

By the late nineteenth and twenty centuries European legal codes had replaced Islamic and local customary laws. The political economic and legal penetration of Muslim societies by the West was further extended as modern

\footnotetext{
50 John L. Esposito (ed.), Islam in Asia (Oxford, N.Y.: Oxford University Press, 1987), see editor Introduction, pp. 12-13.
} 
Western educational reforms were introduced. Traditional Political and religious elite saw their power, prestige and way of life (custom and values) progressively altered by new modern Western oriented classes of professional and technocrats. By twenty the century, the West reigned supreme, dominating much of the Islamic world politically and economically. Its impact on social and cultural life was no less threatening. ${ }^{51}$

In fact, in some cases Western colonialism employed orientalists for their understanding and interpretation of Islam and Muslim society. Edward Said's work suggests that orientalist understandings were generally colored with a Western worldview and political interest. ${ }^{52}$ In turn, such interpretations influenced some modernist Muslim intellectuals, especially those who studied at Western universities.

From this situation at least two emerging religious orientations came to materialize, which developed into two lines of religious cleavage: one approving and adopting a Western Orientalist approach to Islam, the other resisting it. In Indonesia, during the Suharto regime, the former promoted secularism and rationalism, two important doctrines of modernism. After the fall of Suharto this group advocated postmodern doctrines, such as relativism, religious pluralism, nihilism, and the likes. These intellectuals were known among the Indonesian Muslims as liberal Muslims but they called themselves Liberal Islam (Islam Liberal). In contrast, the latter branch disseminated the spirit of Islamic revival and maintaining a traditional understanding of Islam. Some were against the West, but others were rationally critical of both Islam and the West. These two lines of religious cleavages were supportive of socio-political movements in today's Indonesia.

To use a fair and objective designation to depict Muslim movements in relation to an Islamic worldview and the present political situation, I avoid using the liberal-literal division. Instead, I would prefer to employ the terms "liberal" and "non-liberal", since liberal-literal usually suggests that the former is positive, whereas the latter is negative. The word "liberal" is often associated with demo-

\footnotetext{
${ }^{51}$ Esposito, Islam, pp. 15-16.

52 Edward Said identified three fundamental misunderstanding of the Orientalism in his work Orientalism, but to grasp directly the three point see Keith Windschuttle "Edward Said's Orientalism revisited," The New Criterion Vol. 17, No. 5, (January 1999), p. 5 .
} 
cratic, moderate, tolerant, humanistic, rational, whereas the word "literal" is not. Moreover, to place liberal vis a vis literal is to neglect the non-liberal and non-literal approaches to Islam which in turn might lead to the generalization that all Muslims are literalists, fundamentalists and terrorists. This, according to Esposito, tends to be misleading. He states that:

To equate Islam and Islamic fundamentalism uncritically with extremism is to judge Islam only by those who wreak havoc--a standard not applied to Judaism and Christianity... ${ }^{53}$

Cheryl Bernard's classification of Muslims into: fundamentalist, traditionalist, secularist and modernist ${ }^{54}$ also appears problematic, since it is hard to distinguish between fundamentalists and traditionalists, because as I mentioned above, Muhammadiyah is modernist but by no mean liberal, while NU is traditionalist and could be in a sense fundamentalist. The same is the case with Justice Party, which is modernist in a sense and fundamentalist in another. Similarly, in some cases there is an overlap between secularists and modernists. Therefore, the category of liberal and non-liberal would be more appropriate in relation to Islam. ${ }^{55}$

\section{The Non-Liberal groups}

A non-liberal approach to Islam refers to the Sunnischool of thought or Ablussunnah wal Jama the largest school of thought adhered by Indonesian Muslims and Muslims in the wider world. It is within this school that Maliki, Hanafi, Hanbali and Syafii schools of jurisprudence, as well as Asy'ari and Maturidi schools of theology existed. Admittedly, there are various versions of Islamic teaching in this Sunni roup, such as the role of reason and revelation, various legal

\footnotetext{
53 John L. Esposito, "Political Islam: Beyond the Green Menace," Originally published in the journal Current History, (January 1994). Cited from http://www.arches.uga.edu/ godlas/espo.html. Accessed on 25 September 2008.

54 The modernist meant by Cheryl is in fact the liberalist. See Cheryl Bernard, Civil Democratic Islam, Partners, Resources and Strategies (Pittsburgh: RAND Corporation, 2003), pp. 44-55.

${ }^{55}$ Liddle divides the religious cleavage into Liberal and Islamist, but by Islamist he refer only to the radical group excluding the moderate one. See William Liddle, "New Patterns of Islamic Politics in Democratic Indonesia," Asia Program Special Report, no. 110, (April 2003).
} 
decisions. Still, their diverse approaches are still within the ambit of the worldview of Islam.

In the case of Indonesian Muslims the non-liberal approaches are divided into groups, each of which has its own particular interest. As was described above, among the largest groups or organizations are: Muhammadiyah, (emphasizes on social movements), Nabdatul Ulama or NU (maintaining traditional spirit of Islam), al-Irsyad (stressing on understanding Islam based on the Salafi school of thought), and traditional Islamic boarding schools, named Pesantren, spread all over Indonesia. All of those organizations and education institutions played a pivotal role in the struggle for Indonesia's independence and, in fact, militancy in Indonesia can be said to go back to the early attempts of these organizations and other Muslim organizations in the struggle against the Portuguese and later Dutch colonizers. After independence these organizations became a force for progressive political change, advocating religious tolerance, taking moderate positions, protecting civil rights, empowering women for social activities, ${ }^{56}$ and helping the poor. At the same time, they also promoted Islamic values, traditions and practices, and in some cases might advocate Islamic law, however, they were committed to working within the law, and as part of the political system to advance their goals.

Be that as it may, voice of Islam in Indonesia is not represented only by these large, powerful, and moderate organizations. Other than those moderate organizations, historically, there were also "radical" movements in Indonesia whose membership in part consisted of Indonesian military and civilian combatants demobilized after the establishment of the Republic. An organization that has often been stigmatized as militant Islam in Indonesia is Daral Islard(DI). Daral Isla had its roots in separate rebellions in West Java, South Sulawesi and Aceh in the late 1940s and early 1950s. D.I sought to create an Islamic state, Negara Islam Indonesia (NII). In fact, the movements emerged due to a conflict that occurred between the military and Soekarno's authoritarian strategy. But the military subsequently took refuge under the umbrella of Islam, declaring the establishment of a separate Islamic state. This became a strategic reason for the Indonesian Army during Suharto regime to be as highly suspicious of

${ }^{56}$ For this purpose Muhammadiyah formed women organization named Aisyiah, while Nabdatul Ulama has Muslimat for women and Fatayat for female youths. 
political Islam as it was of the communists. ${ }^{57}$ Such a suspicion was inappropriate for it included moderate Muslims in general. It is still too early to consider the present social and political movements as the reemergence of those radical and separatist movements (Daral Isla and further research is needed into this question..$^{58}$

At present the groups which are usually dubbed fundamentalist in Indonesia are the Islamic Defenders Front (FPI), the Mujahidin Council of Indonesia (MMI), Laskar Jihad, and one other group, known as Jama Islariyah, which was accused of the October 2002 bombings in Bali, followed in 2003 and 2004 by the bombings of the Marriott Hotel, and the Australian Embassy in Jakarta.

The Islamic Defenders Front (FPI) is a group formed in 1998 and led by Habib Rizq, an Arab of Yemeni descent, who graduated from Umm al-Qura University and the University of Malaya, Malaysia. Its members are young uneducated activists and partly the activists of various mosques. It is now considered one of the Muslim pressure groups in the country and, in October 2001, it was able to organize demonstrations of over 10,000 people in Jakarta.. The primary concern of this group is to act upon the Prophetic injunction that "Whoever observes an objectionable deed should change it with his hand, if he is powerless he should change it with his tongue, and if he is powerless he should change it with his heart, and that is the weakest faith" (al$H$ ddit $)$. In line with this, the targeted objects of FPI are public places that, for them, facilitate the practice of objectionable deeds (munkarał such as gambling dens, discos, nightclubs and bars that serve alcoholic beverages, and brothels. The objective of this group is that the Islamic law be applied in Muslim society in Indonesia, while Indonesia is regarded as the place of Muslim society. In many occasions Habib Rizq has acknowledged that he never wishes to use violence. Before he and his members force the closure of any forbidden places, he first takes legal procedures by warning the owner of those places to close their businesses, and then by asking the formal and written permission of

\footnotetext{
${ }^{57}$ Further discussion about this see C. van Dijk, Rebellion under the Banner of Islam: the Darul Islam in Indonesia (Leiden: The Hague-Martinus Nijhoff, 1981).

58 It is because Dijk explains that from 1977-1982 virtually the entire leadership of Darul Islam was arrested, while there are split and power struggles at the top. See Dijk, Ibid., and International Crisis Group, "Recycling Militants in Indonesia: Darul Islam and the Australian Embassy Bombing," Asia Report, No. 92, 22 February 2005.
} 
police as well as the approval of the surrounding society for their actions. Nevertheless, he believes, in practice violent actions have to be taken. ${ }^{59}$

Such a movement reminds us of the Hanbalite legal school of thought, founded by Ahmad ibn Hanbal, who claimed to be follower of Salaf. The characteristic of this school was its fanaticism and its frequent conflict with others without argumentation and demonstration, but only with act and deed. Their disagreement with a rational interpretation of the Qur'an was also a salient feature of the Salafi School. Their movement was simply to perform the Islamic obligation "to command the good and forbid the objectionable" (alamr bi al-ma'rufana al-naby 'an al-munkars. Ibn Athir sketched this school as follows: "...if they found female singers they would beat them and smash the music instruments; if they saw man, woman and children walking together they would ask their marital status. If they did not respond they would beat them and bring them to police office." 60 Because of this attitude, according Abu Zahrah, people ran away from them.

Another fundamentalist group is Laskar Jihad, which was formed in 1999 to support their Muslim brothers who were in conflict with Christians in Ambon, in the Maluku islands. The population of the region was almost evenly divided between Christians and Muslims, and no physical conflict had ever happened in the history of the region, but by June 2000, the newly established Laskar Jihad had sent 3,000 members to Ambon. With the support of some Indonesian military officers, Laskar Jihad hoped to establish control over Ambon, thus encouraging the fundamentalist Christians to establish their long gone dream of a separate Christian state. While a settlement was reached on February 12, 2002 and a zone of neutrality established between the two sides, 5,000 people from both sides were slaughtered and 700,000 people became refugees. However, this group is not well organized, has no formal structure, has no long term objectives or program. ${ }^{61}$

\footnotetext{
59 Personal discussion with Faried, one of FPI members, at Jakarta, on 23 August 2003.

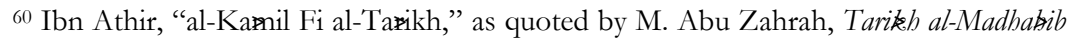

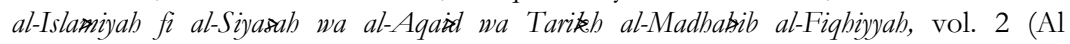
Qałroh: Dar al-Fikri al-'Arabi, 1987), p. 543.

${ }^{61}$ For a discussion of the creation of Laskar Jihad, see Noorhaidi Hasan, "Faith and Politics: The Rise of the Laskar Jihad in the Era of Transition in Indonesia," Indonesia,
} 
After the Maluku conflict, it disbanded its 15,000-member organization.

Another group, regarded as the most radical Islamic group operating in Indonesia, is Jama Islariyah (JI) with Abu Bakar Ba'asyir as its alleged leader. In fact, Ba'asyir had already adopted an extreme position back in the Suharto regime, during which he was against the use of national anthem and flag, Pancasila as the state principle and other national attributes. He was of the opinion that Indonesia should be an Islamic state and shari'a law should be applied. It was due to this position that he escaped to Malaysia in 1985 to avoid continued imprisonment by the Soeharto government. Returning to Indonesia in 1999, Ba'asyir established the Indonesian Mujahidin Council (MMI). According to Ba'asyir, "The MMI is an institution where a lot of people from a lot of Muslim groups including the $\mathrm{NU}$ and Muhammadiyah gather at one table to discuss how to get our vision of shari implemented into national laws. As long as Muslims are the majority, the country should be ruled by shari 7 ." 62

A survey conducted in November 2002 by the Center for Study of Islam and Society (PPIM) at the State Islamic University in Jakarta showed that 71 percent of respondents supported the application of syariah (Islamic law) by the state to all Muslim men and women, and 54 percent said that radical Islamist movements to implement syariah, such as the radical Islamic Defenders Front (Front Pembela Islam (FPI) and Laskar Jihad) must be supported. While many people question the accuracy of the poll, almost everyone agrees that disillusion with secular democracy is growing and more people are turning to Islamist solutions.

Nevertheless, all those radical movements do not represent all Muslim organizations and movements and proponents of radical Islam remain a small minority. Most devout practitioners of Islam who take moderate positions would never dream of using violence. It is only

73 (April 2002), pp. 145-169.

62 As quoted by Lawrence C. Reardon, "A Rational Choice Interpretation of Political Islam's Challenge to Southeast Asia," (Paper presented at the New England Political Science Association, Annual Meeting, Portsmouth, New Hampshire, 30 April 2004), p. 13; see also Zachary Abuza, "MMI Concludes its first Congress Since the Release of Abu Bakar Ba'asyir," Counterterrorism Blog, http://counterterrorismblog.org. Accessed on 06 July 2006. 
their extravagant activities, massive coverage by media of their activities, and the fierce response against their activities by their opponents, that create the image of the exaggerated influence of the radicals. The most extreme response is generally from the liberal group which takes liberal approach to Islam. Nevertheless, it is wise to be alert to the possibility of individuals making common cause with international criminals of whatever religious denomination. ${ }^{63}$

\section{The liberal Group}

The Liberal approach to Islam emerged only recently, almost at the same time as the rise of radical movement after the Reformation era, yet its roots are found in the secular notions of Nurcholish Madjid in 1970s. Among the liberal groups is one called Liberal Islam. It was first enunciated in 1999, initiated by a group of Jakarta-based intellectuals led by Ulil Absar Abdalla, a graduate of Saudi Arabia Institute of Islamic Studies Jakarta (LIPPIA) and now of Emory University, and Luthfi Assyaukanie, graduate of University of Jordan and ISTAC Malaysia and later University of Melbourne Australia. Liberal Islam was known at first by the acronym "Islib", but later in March 2002, the name was altered to the Liberal Islam Network (Jaringan Islam Liberal) so as to disseminate its views through the media networks. Islib originated from an intensive discussion group of young intellectuals at Paramadina University, a Jakarta-based university founded by Nurcholish Madjid. Since it was allegedly not welcomed by the university lecturers, they moved to Utan Kayu Street in East Jakarta under the support of Gunawan Muhammad, former editor in chief of TEMPO magazine.

The movement became more intensive and came up with extreme ideas after the dramatic tragedy of 11/9. They established an active website (www.islamlib.com) and moderated chat groups, islamliberal@yahoogroups.com. Using these two media they debated issues, criticized current understanding of Islam, and cited the Koran to support their liberal arguments. In addition, members of "Liberal Islam" write a syndicated Sunday column published in the widely circulated Jawa Pos daily newspaper and forty regional newspapers including Riau Pos (Pekan Baru) and Fajar (Makassar). They also have a weekly talk show broadcasted every Thursday by Radio $68 \mathrm{H}$ and is

${ }^{63}$ http://www.crisisgroup.org/home/index.cfm?id=1765\&I=1. 
relayed by 20 other radio stations throughout Indonesia. They have formed the Liberal Islam Writers Syndicate and have published booklets and pamphlets on controversial issues such as jihat shari and the establishment of houses of worship. ${ }^{64}$ Their agenda is to disseminate secularism, liberalism, emancipation, religious pluralism, gender and feminism, democratization, tolerance and human rights. Other than the "Liberal Islam Network" there are numerous newly established NGOs and study groups promoting the liberal thought. Among activists who disseminate liberal thought are the lecturers of State Islamic Universities (UIN) and State Institute of Islamic Studies (IAIN).

The fundamental ideas held by "Liberal Islam" are parallel to religious liberalism that prevails in the West. It advocates a secular, relativist and rationalistic approach to Islam with special emphasis on liberal interpretation of the Qur'an. The principle looks simple and rational, but in the writing of its exponents in the media, books or journal articles, it becomes so extreme that it provokes a negative response from not only the radical groups but also the rest of the moderate Muslims. Among the points of dispute of the liberal principles that have created controversies and criticism are: 65

First, opening the gate of ijtihad for all aspects of Islam. This is not new for Sunni>Muslims, but ijtihad for all aspect of Islam is a controversial point. It is because in the history of Islam there was no ijtiha on the definite matter (mubkama such as on the prohibition of alcoholic beverages, obligation of five times daily prayers, hajj pilgrimage, fasting, following the rules of inheritance (fara'id)\} and the like. The liberals refer to no authority in their exercise of ijtiha An example of their opinion is that some Indonesian liberal thinkers justify the practice of same-sex relationships (gays and lesbians), ${ }^{66}$

\footnotetext{
${ }^{64}$ Santi W.E. Soekanto, "'Liberal' and 'Literal' Islam must sit and talk together," The Jakarta Post, 1 March 2002; see also Adian Husaini \& Nuim Hidayat, Islam Liberal, Sejarah, Konsepsi, Penyimpangan dan Jawabannya (Bandung: Gema Insani Press, 2002), p. 4. ${ }^{65}$ See Website of "Liberal Islam," http://www.islib.com.

${ }^{66}$ Recently pronounced by Siti Musdah Mulia, is a feminist and was researcher in Research Development Bureau of Ministry of Religious Affairs, that lesbianism is legally allowed in Islam.
} 
prohibit polygamy, ${ }^{67}$ and state other provocative opinions. These and other opinions not only look unusual, but also are considered deviant among mainstream scholars (ulama).

Second, giving an uncommon preference to contextual interpretation of the Qur'an; this principle is not always consistently followed, for when the text is against their ideas they interpret it contextually; conversely when the text agrees with their argument they take it literally. The most extreme outcome of this is that their emphasis on context leads them to denigrate the text and might result in the assumption that numbers of Qur'anic verses are irrelevant today. This position is intended to counter the literal interpretation of the Hanbalite school, but the drawback is that they only emphasize the contextual interpretation. The mainstream of Sunnischolars maintain a balance between textual and contextual interpretations. This is a serious point of dispute with the liberal group. An unusual point among the scholars of Tafsir is that they employ a method of biblical hermeneutic common to Christian theologians to interpret contextually the Qur'anic text. The liberals hold that the science of Tafsir, constructed by Muslim scholars in the past, caused the moral, political and cultural decadence of the Muslims, a big claim that would put at risk the existing Islamic education institutions and is against the majority of Muslims scholars.

Third, believing the relativity of truth. This principle leads to the belief that no one knows the true teaching of Islam, and no one knows the truth according to the will of God. Only God knows the absolute truth. Therefore, there is no claim of absolute truth. This principle is the foundation of religious pluralism, but liberal activists are disagreed over this issue. Some hold that pluralism is admitting the plurality of religions as religious tolerance, ${ }^{68}$ but some others argue that pluralism is a belief that all religions are different ways to God. The most crucial point, one which diametrically opposes the fundamental belief of the Muslims, is the assertion that Islam is not the only true religion and Allah is a name of God at an exoteric level, while there is another God

\footnotetext{
${ }^{67}$ See Counter Legal Draft of Compilation of Islamic Law, compiled by a team chaired by Siti Musdah Mulia.

${ }^{68}$ H. Nuhrison M. Nuh, "Faham-faham Keagamaan Liberal di Kota Medan," (Paper presented at a seminar on Liberal thought at Rural Communities, Research and Development Bureau, Ministry of Religious Affairs, 15 November, (2006), p. 12.
} 
at an esoteric level. Therefore, they believe that all religions are true and the goal of worship in all religions is one that is towards The One. ${ }^{69}$ This idea is purely a derivation of John Hick's conception of Global theology. In fact, pluralism is problematic not only for the Muslims but also for the adherents of Christianity. ${ }^{70}$ Thus, there is no clear definition of religious pluralism among the liberal proponents.

Fourth, believing in the religious freedom. This principle is derived purely from the principle of religious liberalism, implying that full religious freedom means not only freedom to perform religious duties or to believe in one religion, but also freedom not to embrace any religion or freedom to become an atheist. ${ }^{71}$ In Islam one is free to embrace Islam or another religion, but once becoming a Muslim, he or she must perform religious duties. Indonesia is neither a religious nor a secular state, but atheism as adhered to by communism has no place, since it is against the first principle of Pancasila (Five Principles) i.e. "Belief in the Absolute One God"

Another liberal principle is the idea of secularism, that is, to keep separate worldly and religious authority, and to keep religion out of politics. Many, if not most, aspects of social life, including the state, are outside the direct purview of religion. This idea might effectively prevent the idea of an Islamic state, but to isolate the socio-political activities of Muslims from their religious obligation is impossible. For the moderate Muslims no aspect of social life, most especially the state, is outside religion. The extreme position held by the exponents of the liberal group is their demand to abolish the Department of Religious Affairs and Ulama Council of Indonesia (MUI), ${ }^{72}$ for the two are

\footnotetext{
${ }^{69}$ Statement of Nurcholis Madjid as quoted by Achmad Rosidi in "Liberal Masyarakat Kota Yogyakarta," (Paper presented at a Seminar of Research Result about Liberalism Thought in Rural Community at Yogyakarta, 2006, held by Research and Development Bureau, Ministry of Religious Affair, Jakarta, November 2006, p. 31.

${ }^{70}$ Kenneth R. Samples, "The Challenge of Religious Pluralism," in Cbristian Research Journal, Summer (1990), p. 39.

${ }^{71}$ Nicholas F. Gier, "Religious Liberalism and the Founding Fathers," in Peter Caws (ed.), Two Centuries of Philosophy in America (Oxford: Basil Blackwell Publishers, 1980), pp. 22-45.

72 The idea was pronounced in a session of VIIth National Symposium of Human Right, held by National Commission of Human Right (KOMNAS HAM), Borobudur Hotel, Jakarta, 8-11 June, 2008.
} 
symbols of integration of religion and state, placing religion as a question of public concern rather than a purely private matter.

It is not hard to trace the origin of these liberal ideas. It was initially motivated by the spirit to respond to the Western notion of modernism. Among the early liberal Muslim thinkers in Indonesia were Harun Nasution and Nurcholish Madjid, ${ }^{73}$ both graduates of Western universities. However, other exponents like Masdar F. Mas'udi, Hussein Muhammad, Hamid Basyaib, Ulil Absar Abdalla, Luthfi Asysyaukani and others were not graduates of Western universities. Surprisingly, most of them were graduates of either traditional or modern religious schools (pesantren). However, there is an indication that the root of their liberal thoughts lay not in their creative and innovative understanding (ijtiba of Islamic tradition, but in their attempts to apply an understanding of Postmodern Western thought to Islamic thought. Unsurprisingly the ideas of liberal exponents mostly perplexed students of traditional schools (pesantren), for there is no trace of such ideas in the Muslim intellectual tradition. This is the reason why liberal thought spread only among young Muslim scholars in big cities. Still, it had the effect of causing curiosity, criticism, hatred and confusion among the masses.

\section{US Involvement}

One of the most instrumental factors behind the spread of the liberal movement is financial support from the United States government. Most Indonesian Muslims, became aware of this after the terrorist attacks of September 11, 2001. The aim of the US government is not only to fight terrorists but also to change the Muslim world's attitude towards the United States. The targets are the extreme Muslim activists or the "fundamentalists" in the Western sense of the word, who are regarded as contributing to terrorism. To crush terrorism and fundamentalism the US government gives financial support to NGOs and Muslim organizations to disseminate

\footnotetext{
${ }^{73}$ Harun Nasution, the graduate of McGill Islamic Studies, Canada, and Nurcholish Madjid the Chicago University trained Islamic scholar, played a pivotal role in disseminating secularism, rationalism, religious pluralism and other fundamental ideas of liberalism. They were also known as scholars who promoted a version of Islam that was acceptable to New Order Government. See Malcolm Cone, "Neo-Modern Islam in Suharto's Indonesia," New Zealand Journal of Asian Studies, 4, 2 (December 2002), pp. $52-67$.
} 
the idea of democracy, human rights, religious pluralism, moderation, modernity, civil society, gender equality, feminism and the like. US funds are used for broadcasting Islamic radio and TV shows, arranging democracy training, developing a curriculum in Muslim schools on civic education, holding seminars and meetings on civil education, and conducting other programs that promote liberal Islam.

Several programs backed financially by the US can briefly mentioned here. For instance, USAID is actively involved in this sphere through such programs as the Muslim World Outreach and Engaging Muslim Civil Society Program. USAID funds also go through the Toyota Asia Foundation (TAF) to a wide range of 32 organizations and institutions under its overarching program called Islam and Civil Society (ICS). It also collaborates with Muslim leaders and organizations to support democracy training and civil society development programs. These are offered at the State Islamic University in Jakarta and at Muhammadiyah University in Yogyakarta. Among other groups that it funds is ICP. It coordinates and financially supports JIL's radio talk show on "Islam and Tolerance". Likewise, it helps fund the female youth corps of Nahdlatul Ulama in establishing 20 domestic violence counseling centers and women's advocacy centers. It also provides financial assistance to Muhammadidyah and NU for a variety of educational initiatives. The program has contributed to strengthening its local Indonesian partners, and has widened a national conversation about democracy, human rights, and gender equality. However, USAID and the Asia Foundation never realize the impact of this liberalization movement on the non-liberal groups. Apart from political interest the most serious problems with liberal thought concern the fundamental aspects of Islamic teaching.

Since the "Liberal Islam" stance often seems relatively unsympathetic towards mainstream Muslims, many Muslims have become suspicious of the liberal movement. This, in turn, has resulted in a significant decrease in the popularity of the US government under the Bush administration. One of the exponents of Liberal group admits that his liberal colleagues "are sometimes too direct in their approach, insensitive in many cases to the feelings of their fellow Muslims, and too selective in the themes and subjects they address..." and they depend too much on Western sources in defending their ideas, and therefore are identified with a Western agenda. In addition, the liberal exponents have a tendency to air controversial ideas through 
the mass media, often pronounced in a subjective fashion and without prior studies of the religious text. These factors reduce the influence of their appeal and the prospects of liberal Islam in Indonesia. ${ }^{74}$

Responses towards the liberal movement have been not only negative but sometimes filled with hatred and animosity. There are various kinds of response from activists, scholars, ulama, and public figures. For the non-liberal activists, "Liberal Islam" is anathema. Instead of adhering to the doctrines and teachings of Islam, the proponents of "Liberal Islam" are perceived as reinterpreting texts handed down by the Prophet to suit their own convenience. 'Islib' is regarded as a group of secularists who are spreading confusion and disinformation among the masses. ${ }^{75}$ Interestingly, the debate between the Muslim fundamentalists and liberals mirrors similar debates between Christian fundamentalists and liberals.

In its 7th Congress the Council of Indonesian Ulamas (MUI, "Majlis Ulama Indonesia"), which took place in Jakarta in late July 2005 , issued a fatwa declaring religious liberalism, secularism, and religious pluralism as hrare (forbidden), because these values are described as being incompatible with true Islam. In its statement, the council defines religious liberalism as Islamic thought that is not based on a religious foundation, but which instead subscribes to the absolute freedom of human intellectual capacity. Officially, the MUI fatwas have the backing of 26 Islamic organisations. These have, however, issued statements calling on the people to take up the fatwas in a considered and calm way, and to resolve any differences of opinion in a "civilised" manner through dialogues and encounters. This fatwa is a definite blow to the growing influence of progressive and liberal Muslim movements like the Liberal Islam Network ("Jaringan Islam Liberal", JIL).

According to Ma'ruf Amin, the chairman of the Fatwa Commission of MUI, the liberal movement has deviated from the teaching of Islam. First their method of thinking is not based on Islamic approaches; they have departed from the approaches settled by

\footnotetext{
${ }^{74}$ M. Ihsan Alief, "Political Islam and Democracy: A Closer Look at the Liberal Muslims," Asia Program Special Report, no. 110 (April 2003), p. 15.

${ }^{75}$ For criticisms of "Liberal" by supporters of non-liberal approach to Islam, see the website of the Indonesian Islam Information and Communications Centre (http://www.alislam.or.id).
} 
ulama. Second, they consider the Qur'anic verses as irrelevant for today's needs and therefore they modify their meaning to fit with the global situation. Furthermore, Ma'ruf denies that MUI has killed freedom and diversity by this fatwa. Rather, MUI only killed the deviation. "Ahmadiyah, secularism, pluralism and liberalism are not diversity in Islam, but deviation, since we have our own standards of tolerance." 76

This resistance shown by moderate groups towards liberal proponents was exemplified by the election of Hasyim Muzadi as the chairman of Nabdatul Ulama, the defeat of the liberal Abdurrahman Wahid, and also the election of Din Syamsuddin, a non-liberal figure, as the chairman of Mubammadiyah organization. Open discourse with the liberal group in an academic atmosphere has also failed, due to their different approaches. The liberals interpret the texts with logical tool, while the non-liberals understand the texts with reason and authority.

\section{Conclusion}

The gulf that is growing between the supporters of a liberal interpretation of religion on the one hand, and fundamentalist, and radical Islamic currents on the other is quite dangerous for the future unity of the Indonesian nation, especially for the Muslims community. The two have taken up extreme standpoints, one condemning the other. The liberals blame not only the radical interpretation but attack almost the whole Islamic tradition including the fundamental teachings of Islam.

I believe that militant Islamic groups do not have enough support to be considered a major threat to the stability and viability of Indonesian democracy, for the majority of Indonesian Muslims remain moderate. In the political sphere, elections and the democratic processes that have taken root since 1999 have offered hope for the Islamic parties, which gained votes in 2004 election not only because of their moderate causes, but also because of the outstanding performance and integrity of their members in the parliament. Finally, it is safe to assert that the future of Islamic political parties will be in the hands of the moderate Muslims who uphold religious tolerance,

76 "Kampanye JIL Bukan Sekedar Wacana," Hidayatullah, 1st Edition/XIX, Media, 2006, Rabiuthani, 1427. 
appreciate the diversity of races and religions, promote not only human rights but also human obligations to God, help the poor and cooperate with other nations in politics, economics, education and the social welfare of human beings. []

\section{Bibliography}

\section{Books and Articles}

"Counter Legal Draft of Compilation of Islamic Law." compiled by team chaired by Prof. Dr. Musdah Mulia. Research and Development of Religious Affair Department.

Alief, M. Ihsan. "Political Islam and Democracy: A Closer Look at the Liberal Muslims." Asia Program Special Report. no. 110 (April 2003).

Barton, Greg. Gus Dur: The Authorized Biography of Abdurrabman Wabid. Jakarta: Equinox Publications, 2002.

Benda, Harry J. The Crescent on the Rising Sun, Indonesian Islam under the Japanese Occupation, 1942-1945. Netherlands: The Hague-W. Van Hoeve, 1958.

Bernard, Cheryl. Civil Democratic Islam, Partners, Resources and Strategies. Pittsburgh: RAND Corporation, 2003.

Brownlee, John Malcolm. Scripturalism and Religious Liberalism on Yogyakarta Campuses. MA thesis, Ohio University, 1997.

Collins, Elizabeth Fuller. "Dakwah and Democracy; The Significance of Partai Keadilan and Hizbut Tharir." Unpublished paper. Fulbright Visiting Fellow Universitas Islam Negeri Syarif Hidayatullah, Jakarta.

Cone, Malcolm. "Neo-Modern Islam in Suharto's Indonesia." New Zealand Journal of Asian Studies. 4, 2 (December 2002): pp. 52-67.

Dhume, Sadanand. "Hiøbut Tabrir Using War in Iraq to Seek Converts." Far Eastern Economic Review, 3 April (2003).

Dijk, C. van. Rebellion under the Banner of Islam: the Darul Islam in Indonesia. Leiden: The Hague-Martinus Nijhoff, 1981.

Esposito, John L. (ed.). Islam in Asia. Oxford, N.Y.: Oxford University Press, 1987.

". "Political Islam: Beyond the Green Menace." Current History. (January 1994). 
Faith, H. The Decline of Constitutional Democracy in Indonesia. Ithaca, N.Y.: Cornel University Press, 1962.

General Election Commission of Indonesia. Analyzing Indonesia's Election,1999. Jakarta: Indonesian General Election Commission, 2001.

Gier, Nicholas F. "Religious Liberalism and The Founding Fathers." in Peter Caws (ed.), Two Centuries of Philosophy in America. Oxford: Basil Blackwell Publishers, 1980.

Hasan, Noorhaidi. "Faith and Politics: The Rise of the Laskhar Jihad in the Era of Transition in Indonesia." Indonesia, 73 (April 2002): pp. 145-169.

Hefner, Robert W. "Islam, State and Civil Society: ICMI and the Struggle for the Indonesian Middle Class." Indonesia. No. 56 (1993): pp. 1-35

-. Civil Islam. Princeton, NJ: Princeton University Press, 2000.

Hunter, Shireen T. "Religion, Politics and Security in Central Asia." SAIS Review, 21, No. 2 (Summer-Fall 2001): pp. 72-81.

Husaini, Adian and Nuim Hidayat. Islam Liberal, Sejarah, Konsepsi, Penyimpangan dan Jawabannya. Bandung: Gema Insani Press, 2002.

International Crisis Group. "Recycling Militants in Indonesia: Darul Islam and the Australian Embassy Bombing." Asia Report, No. 92, February. 22, (2005).

King, Dwight. Half-Hearted Reform: Electoral Institutions and the Struggle for Democracy in Indonesia. Westport, CT: Praeger, 2003.

Koentjaraningrat. Javanese Culture. Singapore: Oxford University Press, 1985.

Kurzman, Charles (ed.). Liberal Islam: A Sourcebook. Oxford: Oxford University Press, 1998.

Liddle, R. William "The Islamic turn in Indonesia: A Political Explanation." The Journal of Asian Studies, 55, no. 3 (August 1996): pp. 613-634.

-. "New Patterns of Islamic Politics in Democratic Indonesia." Asia Report Special Program. no.110, April (2003).

------.. Leadership and Culture in Indonesian Politics. Sydney: Allen and Unwin, 1996. 
Naipaul, V.S. Among the Believers: An Islamic Journey. London: A. Deutsch, 1981.

--------. Beyond Belief: Islamic Excursions Among the Converted Peoples. New York: Random House, 1998.

Nuh, H. Nuhrison M. "Faham-faham Keagamaan Liberal di Kota Medan." Paper presented at a seminar on Liberal thought at Rural Communities, Research and Development Bureau, Department of Religious Affair, 15 November 2006.

Porter, Donald. Managing Politics and Islam in Indonesia. London: Routledge, 2002.

Reardon, Lawrence C. "A Rational Choice Interpretation of Political Islam's Challenge to Southeast Asia's." Paper presented at the New England Political Science Association, Annual Meeting, Portsmouth, New Hampshire, 30 April 2004.

Rosidi, Achmad. "Liberal Masyarakat Kota Yogyakarta." Paper presented at a Seminar of Research Result about Liberalism Thought in Rural Community at Yogyakarta, held by Research and Development Bureau, Department of Religious Affair, Jakarta, November 2006.

Samples, Kenneth R. "The Challenge of Religious Pluralism." Christian Research Journal, Summer (1990).

Smart, Ninian Worldview, Crosscultural Explorations of Human Belief. New York: Charles Sribner's sons, n.d.

Suryadinata, Leo. "A Year of Upheaval and Uncertainty: The Fall of Soeharto and the Rise of Habibie." Southeast Asian Affairs. Singapore: Institute of Southeast Asian Studies, 1999.

Tarrow, Sidney. Power in Movement: Social Movements and Collective Action in Politics. Cambridge: Cambridge University Press, 1994.

Tilly, Charles. From Mobilization to Revolution. Reading, Massachusetts: Addison-Wesley Publishing, 1978.

. Politics of Collective Violence. Cambridge: Cambridge University Press, 2003.

Vatikiotis, Michael. Indonesian Politics Under Subarto. London: Routledge, 1994. 
Wahid, Hidayat Nur and Zulkiflimansyah. "The Justice Party and Democracy: A Journey of a Thousand Miles Starts with a Single Step." Asia Program Special Report. no 110, (April 2003).

Wald, Kenneth D. and C.D. Smidt. "Measurement Strategies in the Study of Religion an Politics." in David C Leege (eds). Rediscovering the Religious Factor in American Politic. Aemonk, N.Y: R.E. Sharpe, 1993.

Wall, Thomas F. Thinking Critically About Philosophical Problem: A Modern Introduction. Wadsworth, Australia: Thomson Learning, 2001.

Windschuttle, Keith. "Edward Said's Orientalism revisited." The New Criterion. vol. 17, No. 5, (January 1999).

Zahrah, M. Abu. Tari al-Madhation al-Islariyah, fi al-Siyasth wa al-Aqa wa Tari al-Madhatidi al-Fiqhiyah. vol. 2. n.p.: Dar al-Fikri alArabi, 1987.

\section{Electronic Sources}

Abuza, Zachary. "MMI Concludes its first Congress Since the Release of Abu Bakar Ba'asyir." Counterterrorism Blog, http://counterterrorismblog.org. Accessed on 06 July 2006.

http://www.alislam.or.id.

http://www.arches.uga.edu/ godlas/espo.html. Accessed on September 25, 2008.

http://www.crisisgroup.org/home/index.cfm?id=1765\&I=1.

http://www.Islib.com.

Tamimi, Azzam "Hizbut-Tahrir Reflections on its Origin and its Ideas", on http://www.ii-pt.com/web/papers/tahrir.htm.

\section{Newspapers}

"Kampanye JIL Bukan Sekedar Wacana." Hidayatullah, 1st Edition/XIX, Media, 2006, Rabiuthani, 1427.

New York Times, 30 April 2002.

Soekanto, Santi W.E. "'Liberal' and 'Literal' Islam must sit and talk together." The Jakarta Post, 1 March 2002. 